\title{
Karakterisasi $\alpha$-Amilase dari Aspergillus versicolor 3a1 yang Diproduksi pada Media Limbah Cair Tapioka
}

\author{
Characterization of Aspergillus versicolor 3a1 $\alpha$-Amylase Produced on Cassava Liquid \\ Waste Media
}

Fitratul Aini ${ }^{1}$, Nisa Rachmania Mubarik ${ }^{2 *}$, Lisdar A. Manaf ${ }^{2}$

${ }^{1}$ Jurusan Tadris Biologi, Fakultas Tarbiyah, Institut Agama Islam Negeri Sulthan Thaha Saifuddin, Jambi

${ }^{2}$ Departemen Biologi, Fakultas Matematika dan ilmu Pengetahuan Alam, Institut Pertanian Bogor, Bogor 16680

E-mail: nrachmania@ipb.ac.id *Penulis untuk korespondensi

\begin{abstract}
The aim of this experiment was to characterize $A$. versicolor $3 \mathrm{a} 1 \alpha$-amylase produced on cassava liquid waste media. Two types of media, base and combination media, were used as a comparison. Cassava liquid waste media contains 1\% cassava starch, $1 \%$ yeast extract, $0.13 \% \mathrm{KH}_{2} \mathrm{PO}_{4}$, and $0.05 \% \mathrm{MgSO}_{4}$ diluted in cassava liquid waste. Base media contains same composition but using aquadest as a solvent, and combination media using mixture of aquadest and cassava liquid waste. A. versicolor $3 a 1 \alpha$-amylase showed its maximum specific activity in cassava liquid waste, base, and combination media after 3, 7, and 4 days incubation, respectively. Crude extract of $\alpha$-amylase from A. versicolor 3a1 was precipitated in $20-80 \%$ (w/v) ammonium sulphate. Precipitation of $A$. versicolor $3 a 1 \alpha$-amylase with $70 \%(w / v)$ ammonium sulphate on cassava liquid waste, $60 \%$ on base media, and $60 \%$ on combination media will increase its specific activity 16.6, 4.28, and 5.65 times, respectively, compared to the specific activities of crude before precipitation. $\alpha$-Amylase crude extract from $A$. versicolor $3 a 1$ from all media showed its highest specific activity at $7^{\circ} \mathrm{C}$ and $\mathrm{pH} 5.0$, and addition of $\mathrm{FeSO}_{4}$ increased the specific activity. Precipitated $A$. versicolor $3 a 1 \alpha$-amylase from all media showed its highest specific activity at $70^{\circ} \mathrm{C}$ and $\mathrm{pH}$ 6.0. Addition of $\mathrm{FeSO}_{4}$ precipitated $3 a 1 \alpha$-amylase from base and combination media will increase its specific activity, while $\mathrm{MgSO}_{4}$ will increase its specific activity in cassava liquid waste media. Thermostability assay revealed that the crude and the precipitated 3a1 $\alpha$-amylase were relatively stable at $70^{\circ} \mathrm{C}$ up to 180 minutes incubation, except for precipitated $3 a 1 \alpha$-amylase on cassava waste media. Crude $\alpha$-amylase 3a1 was relatively stable at pH 5-9 up to 1 hour incubation with wide pH ranges, while the precipitated with narrow $\mathrm{pH}$ ranges.
\end{abstract}

Key words: $\alpha$-amylase, Aspergillus versicolor 3a1, cassava liquid waste

Diterima: 27 Maret 2009, disetujui: 29 September 2009

\section{Pendahuluan}

Indonesia merupakan negara penghasil bahan-bahan berpati, seperti ubi kayu, pengolahannya menjadi pati banyak dilakukan oleh industri rumah tangga atau industri kecil. Proses pengolahan ubi kayu menjadi tepung tapioka terdiri atas tiga tahap yaitu pengolahan pendahuluan, ekstraksi pati, dan pengolahan akhir. Pada tahap ekstraksi pati banyak dihasilkan sisa bahan yang tidak dipakai lagi dan dibuang (Djubaedah et al., 1994).

Industri tapioka menghasilkan limbah cair dalam jumlah besar yaitu setiap ton singkong memerlukan 800 liter air untuk pengolahannya. Limbah cair ini berasal dari pencucian ubi kayu dan proses pengendapan/ pemisahan pati (Djubaedah et al., 1994). Proses 
pembuatan pati ubi kayu (> 120 juta ton/tahun) menghasilkan hampir 20 juta ton limbah/tahun. Limbah tersebut masih mengandung pati $50 \%$ dan kandungan pati yang cukup tinggi dapat digunakan sebagai substrat untuk pertumbuhan cendawan (Handayani et al., 2002). Bahanbahan tersebut sangat berpotensi apabila dimanfaatkan sebagai substrat pertumbuhan mikrob penghasil enzim terutama amilase. Enzim amilase merupakan kelompok enzim yang dihasilkan mikrob seperti bakteri dan cendawan (Nahas dan Waldemarin, 2002).

$\alpha$-Amilase (1,4- $\alpha$-D-glukan glukanohidrolase, EC 3.2.1.1) banyak dimanfaatkan untuk industri gula cair seperti glukosa, maltosa, dekstrosa, alkohol, dan proses biokonversi pati menjadi monomernya. Sebagai negara yang banyak menghasilkan ubi kayu dan sagu, Indonesia sangat berpotensi untuk mengembangkan industri yang menghasilkan amilase. Nilai ekonomi ubi kayu maupun tapioka akan dapat ditingkatkan apabila dihasilkan produk yang bernilai ekonomi tinggi seperti sirup glukosa, fruktosa, dan maltosa. $\alpha$ Amilase umumnya digunakan pada tahap likuifikasi pati pada proses pembuatan gula cair. $\alpha$-Amilase akan memecah amilosa menjadi glukosa dan maltosa serta sisa oligosakarida yang tidak terhidrolisis. Proses selanjutnya, sakarifikasi, memerlukan amiloglukosidase untuk memecah pati yang menghasilkan glukosa. Agar proses sakarifikasi berjalan optimum, seringkali $\alpha$-amilase ditambahkan pada proses ini untuk membantu amiloglukosidase dalam mempercepat dan meningkatkan kandungan glukosa (Fogarty, 1983).

Kapang merupakan mikrob yang banyak menghasilkan enzim ekstraseluler dan sangat berpotensi digunakan untuk industri enzim. Aspergillus spp. merupakan salah satu jenis kapang yang mempunyai kemampuan tinggi dalam menghasilkan berbagai macam enzim seperti amilase, selulase dan amiloglukosidase. Sebagai contoh, Aspergillus versicolor 3a1 (Handayani et al., 2002) dan A. sydowii K10 (Mubarik et al., 2003) yang diisolasi dari limbah cair tapioka berpotensi sebagai penghasil $\alpha$-amilase ekstraseluler. Naiola (2002) melaporkan bahwa enam isolat Aspergillus spp. yang telah diisolasi dari berbagai sumber mempunyai kemampuan memproduksi enzim amilase. Isolat $A$. niger (ISO 482) dan $A$. clavatus (ISO 468) yang mempunyai aktivitas lebih tinggi dibandingkan empat isolat lainnya mempunyai suhu optimum $40-50^{\circ} \mathrm{C}$ dengan $\mathrm{pH}$ optimum 5.0.

Penelitian ini bertujuan mengetahui potensi $A$. versicolor $3 \mathrm{a} 1$ sebagai penghasil enzim amilase yang diproduksi pada media yang mengandung limbah cair tapioka dan mengarakterisasi $\alpha$-amilase ekstrak kasar dan hasil pengendapan amonium sulfat yang dihasilkannya.

\section{Metode Penelitian}

\section{Peremajaan Isolat}

Aspergillus versicolor 3a1 yang diperoleh dari koleksi Laboratorium Mikrobiologi, Departemen Biologi, FMIPA, Institut Pertanian Bogor ditumbuhkan pada media agar-agar PDA yang mengandung pati tapioka $1 \% \quad(\mathrm{w} / \mathrm{v})$ (Handayani et al., 2002).

\section{Pengukuran Pertumbuhan Kapang}

Empat keping isolat A. versicolor $3 \mathrm{a} 1$ dan A. sydowii $\mathrm{K} 10$ (diameter $0,5 \mathrm{~cm}$ ) yang berumur 7 hari masing-masing diinokulasikan pada tiga perlakuan media, yaitu media limbah dengan komposisi pati tapioka $1 \%$, ekstrak khamir $1 \%, \mathrm{KH}_{2} \mathrm{PO}_{4} 0,13 \%$, dan $\mathrm{MgSO}_{4} \cdot 7 \mathrm{H} 2 \mathrm{O}$ $0,05 \%$ (w/v) yang dilarutkan dalam $25 \mathrm{ml}$ limbah cair pengolahan tapioka yang diambil dari Cimahpar Bogor, media dasar dengan komposisi substrat dan bahan kimia yang sama tetapi dilarutkan dalam $25 \mathrm{ml}$ akuades, dan media kombinasi dengan komposisi substrat dan bahan kimia yang sama tetapi dilarutkan dalam $25 \mathrm{ml}$ campuran akuades dan limbah cair pengolahan tapioka (1:1). pH ketiga media diatur 7,0 dengan menambahkan $\mathrm{NaOH} 1 \mathrm{M}$ atau $\mathrm{HCl} 0,2 \mathrm{M}$. Kemudian setiap media diinkubasi di dalam inkubator suhu ruang $\left(25^{\circ} \mathrm{C}\right)$ dengan goyangan $140 \mathrm{rpm}$ (putaran per menit) selama 8 hari. Mulai hari ke-2 sampai dengan hari ke-8 biakan yang tumbuh pada setiap media disentrifugasi pada kecepatan $5600 \times$ g pada suhu $4^{\circ} \mathrm{C}$ selama 20 menit. Endapan atau massa kapang dikeringkan dalam oven pada suhu $90^{\circ} \mathrm{C}$ selama \pm 3 hari sampai berat konstan. Kurva pertumbuhan kapang 
dibuat berdasarkan bobot kering kapang selama masa inkubasi 8 hari. Dari kurva pertumbuhan akan didapatkan aktivitas $\alpha$-amilase optimum dari ketiga perlakuan.

\section{Pengukuran Aktivitas $\alpha$-Amilase dan Kadar Protein}

Supernatan yang diperoleh dari setiap
masa inkubasi pertumbuhan kapang mengandung ekstrak kasar enzim $\alpha$-amilase. Aktivitas enzim $\alpha$-amilasenya diukur dengan menggunakan reagen asam dinitrosalisilat (DNS) untuk mengukur produk berupa gula preduksi (Handayani et al., 2002). Panjang gelombang $550 \mathrm{~nm}$. Blanko menggunakan akuades sebagai pengganti enzim. Satu unit aktivitas $\alpha$-amilase didefinisikan sebagai jumlah enzim yang reaksinya menghasilkan produk setara $1 \mu \mathrm{mol}$ maltosa per menit pada kondisi pengukuran.

Kadar protein sampel diukur dengan metode Bradford (1976). Bovin serum albumin (BSA) digunakan sebagai standar dengan kadar $0-1,0 \mathrm{mg} / \mathrm{ml}$ dari stok BSA $1 \mathrm{mg} / \mathrm{ml}$ dengan selang $0,2 \mathrm{mg} / \mathrm{ml}$. Aktivitas spesifik (U/mg) didapatkan dari hasil perbandingan aktivitas $(\mathrm{U} / \mathrm{ml})$ dengan kadar protein $(\mathrm{mg} / \mathrm{ml})$.

\section{Produksi Ekstrak Kasar $\alpha$-Amilase, Pengendapan dengan Amonium Sulfat, dan Dialisis}

Delapan keping isolat $A$. versicolor $3 \mathrm{a} 1$ dan A. sydowii K10 (diameter $0,5 \mathrm{~cm}$ ) yang berumur 7 hari masing-masing diinokulasikan pada $200 \mathrm{ml}$ media cair pada tiga perlakuan media yang telah disebut di atas dalam Erlenmeyer $500 \mathrm{ml}$, kemudian diinkubasi pada suhu ruang dengan goyangan $140 \mathrm{rpm}$ sampai mencapai aktivitas $\alpha$-amilase optimum yang didapatkan dari kurva pertumbuhan dan produksi pada masing masing isolat pada masing-masing perlakuan media. Selanjutnya suspensi sel disentrifugasi pada kecepatan 5600 x g selama 20 menit pada suhu $4^{\circ} \mathrm{C}$. Supernatan yang diperoleh mengandung ekstrak kasar enzim $\alpha$-amilase. Ekstrak kasar diukur aktivitas spesifik enzimnya. Kemudian ekstrak kasar diendapkan dengan metode salting out (penggaraman), yaitu dengan menambahkan amonium sulfat secara bertahap mulai dengan kadar 20 - 80\% (w/v) (Scopes, 1987). Campuran didiamkan semalam pada suhu $4^{\circ} \mathrm{C}$, kemudian disentrifugasi dengan kecepatan 7950 x g selama 10 menit pada suhu $4^{\circ} \mathrm{C}$. Hasil sentrifugasi berupa supernatan dan endapan. Endapan yang diperoleh dilarutkan dengan bufer Tris- $\mathrm{HCl} 0,05 \mathrm{M}$ pH 7,0 sebanyak $20 \mathrm{ml}$. Supernatan dan endapan yang telah dilarutkan diukur aktivitas spesifik enzimnya. Selanjutnya enzim hasil pengendapan dengan amonium sulfat didialisis dengan cara sebanyak $3 \mathrm{ml}$ enzim hasil pengendapan dimasukkan ke dalam tabung dialisis yang telah diikat pada bagian ujungnya. Kemudian tabung dialisis yang telah berisi enzim hasil pengendapan tersebut direndam di dalam bufer Tris- $\mathrm{HCl} 0,01 \mathrm{M} \mathrm{pH}$ 7,0 , dikocok pelan dengan pengaduk magnet. Perlakuan dialisis dilakukan pada suhu $4^{\circ} \mathrm{C}$. Setelah setengah jam pertama dilakukan penggantian bufer, begitu juga setelah satu jam dan satu setengah jam dilakukan penggantian bufer. Pada jam ke-9 dilakukan pengukuran aktivitas dan kadar protein enzim yang ada di dalam tabung dialisis.

\section{Karakterisasi Enzim $\alpha$-Amilase}

Enzim yang akan dikarakterisasi diproduksi kembali dengan komposisi media dan kondisi yang sama seperti pada tahap produksi sebelumnya, yaitu menggunakan 500 $\mathrm{ml}$ media dalam Erlenmeyer $1000 \mathrm{ml}$. Masingmasing supernatan kemudian diendapkan dengan kadar amonium sulfat yang menghasilkan aktivitas tertinggi untuk setiap perlakuan media. Selanjutnya endapan dilarutkan dalam $50 \mathrm{ml}$ bufer Tris- $\mathrm{HCl} 0,05 \mathrm{M}$ pH 7,0. Karakterisasi enzim dilakukan pada ekstrak kasar dan enzim hasil pengendapan meliputi penentuan (i) suhu optimum aktivitas enzim, pada kisaran $30-80^{\circ} \mathrm{C}$ (selang $10^{\circ} \mathrm{C}$ ) dengan $\mathrm{pH}$ 7,0 dan waktu inkubasi selama 10 menit, (ii) $\mathrm{pH}$ optimum aktivitas enzim, pada kisaran 4,0-9,0 (selang satu unit) dengan suhu optimum yang diperoleh dari karakterisasi suhu dan diinkubasi selama 10 menit, (iii) pengaruh penambahan kation terhadap aktivitas enzim menggunakan $\mathrm{FeSO}_{4}, \mathrm{CuCl}_{2}, \mathrm{CoCl}_{2}, \mathrm{CaCl}_{2}$, $\mathrm{NaCl}, \mathrm{ZnCl}_{2}, \mathrm{MgSO}_{4}$ dan penambahan EDTA dengan kadar akhir $5 \mathrm{mM}$. Kadar akhir merupakan kadar senyawa kation atau EDTA dalam campuran filtrat enzim dan bufer. 
Kontrol menggunakan ekstrak kasar enzim $\alpha$ amilase dan hasil pengendapan tanpa ditambahkan kation. Aktivitas $\alpha$-amilase diukur pada suhu dan $\mathrm{pH}$ optimumnya.

\section{Kestabilan Suhu dan pH $\alpha$-Amilase}

Kestabilan suhu diukur dengan menginkubasi ekstrak kasar enzim dan hasil pengendapan tanpa substrat dengan kation yang mempunyai aktivitas tertinggi pada suhu optimum selama 180 menit dengan selang pengukuran aktivitas setiap 30 menit. Setelah diinkubasi, setiap sampel enzim diukur aktivitasnya dengan menggunakan pati terlarut sebagai substrat pada suhu dan $\mathrm{pH}$ optimum enzim untuk setiap perlakuan.

Pengukuran kestabilan $\mathrm{pH}$ dilakukan dengan menginkubasi enzim tanpa substrat di dalam bufer pada kisaran $\mathrm{pH}$ 5,0-9,0 pada suhu ruang $\left(30^{\circ} \mathrm{C}\right)$ selama $1 \mathrm{jam}$. Setelah diinkubasi, aktivitas enzim diukur pada suhu dan $\mathrm{pH}$ optimum aktivitas enzim.

\section{Hasil dan Pembahasan}

\section{Pengukuran Pertumbuhan Kapang dan Produksi $\alpha$-Amilase}

Bobot kering $A$. versicolor $3 \mathrm{a} 1$ pada media limbah meningkat dari hari ke-2 hingga hari ke-3 inkubasi yang sekaligus merupakan bobot kering tertinggi yaitu $0,27 \mathrm{~g}$ dan menurun pada hari ke-4 inkubasi (Gambar 1a). Pada media dasar, bobot kering dari masa inkubasi 2 hari terus meningkat hingga hari ke7 inkubasi sebesar 2,70 g dan menurun pada hari ke-8 inkubasi (Gambar 1b). Pada media kombinasi, bobot kering meningkat dari hari ke-2 hingga hari ke-4 inkubasi sebesar 2,52 g dan menurun pada hari ke-5 inkubasi (Gambar 1c).

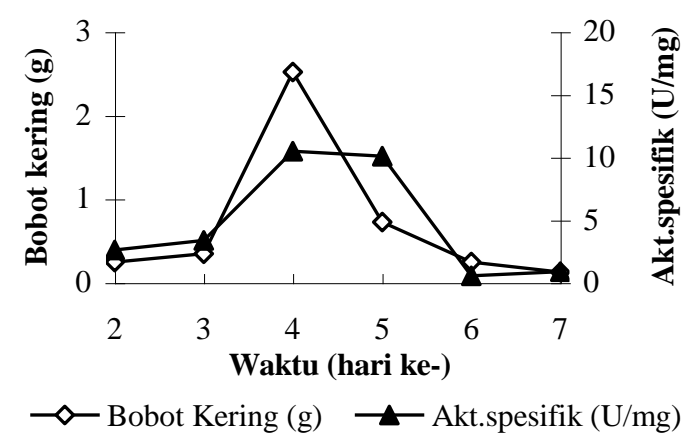

A

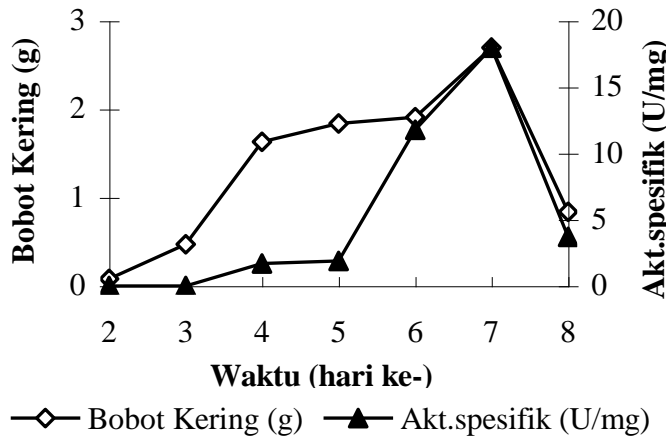

B

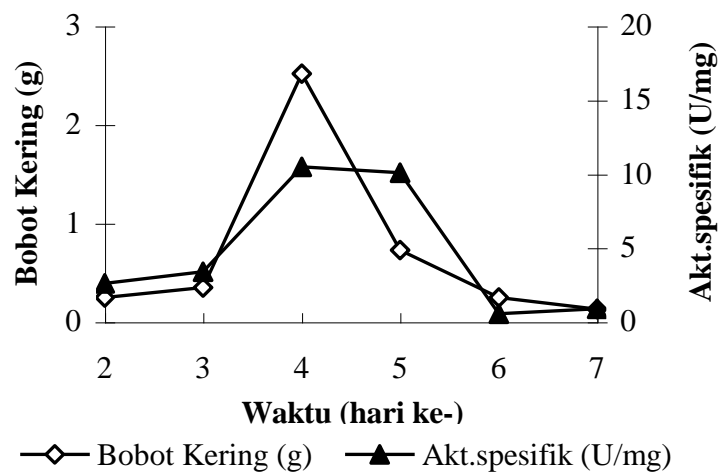

C

Gambar 1. Kurva bobot kering dan aktivitas spesifik $\alpha$-amilase $A$. versicolor 3 a1 yang diproduksi pada media a: limbah, b: dasar, dan c: kombinasi. 
Produksi $\alpha$-amilase A. versicolor $3 \mathrm{a} 1$ pada media limbah langsung terdeteksi pada hari ke-2 dan langsung meningkat dan mencapai maksimum pada hari ke-3 yaitu $13,30 \mathrm{U} / \mathrm{mg}$ pada akhir fase eksponensial pertumbuhan kapang dan aktivitas spesifik menurun pada hari ke-4 inkubasi (Gambar 1a). Aktivitas spesifik $\alpha$-amilase A. versicolor $3 \mathrm{a} 1$ yang diproduksi pada media dasar terdeteksi mulai fase log pertumbuhan pada hari ke-4 dan terus meningkat sampai hari ke-7 pada akhir fase eksponensial yang merupakan aktivitas spesifik tertinggi yaitu sebesar $18 \mathrm{U} / \mathrm{mg}$ dan menurun pada hari ke-8 inkubasi (Gambar1b). Pada media kombinasi, aktivitas spesifik langsung terdeteksi pada hari ke-2, hasil yang didapatkan pada media kombinasi ini lebih mirip dengan hasil pada media limbah. Pada media kombinasi ini, aktivitas spesifik meningkat dari hari ke-2 sampai hari ke-4 inkubasi yang merupakan aktivitas spesifik tertinggi yaitu sebesar 10,50 U/mg dan menurun pada hari ke5 inkubasi (Gambar 1c).

Isolat yang diproduksi pada media limbah mempunyai fase lag yang pendek bila dibandingkan dengan dua media lainnya, hal ini dapat disebabkan kedua isolat tidak membutuhkan waktu adaptasi yang lama untuk pertumbuhannya karena sesuai dengan habitat asalnya yaitu dari limbah cair tapioka (Handayani et al., 2002; Mubarik et al., 2003 \& 2004). Pada media dasar, isolat ini membutuhkan fase lag yang cukup lama sebelum mencapai fase eksponensialnya.

Aktivitas spesifik $A$. versicolor $3 \mathrm{a} 1$ tertinggi pada ketiga perlakuan media dicapai pada akhir fase eksponensial pertumbuhan kapang. Fase eksponensial A. versicolor 3a1 pada ketiga perlakuan media dicapai pada hari yang berbeda. Hal ini diduga oleh perbedaan komposisi nutrien yang ada di dalam ketiga media. Seperti yang dikatakan oleh Griffin (1994) bahwa fase eksponensial sangat dipengaruhi oleh ketersediaan dan perbedaan nutrien di dalam medium. Menurut Madigan et al., (2003), fase eksponensial ini dipengaruhi oleh kondisi lingkungan antara lain, suhu dan komposisi medium kultur.

Setelah mencapai fase eksponensial, selanjutnya terjadi penurunan bobot kering dalam hal ini kapang memasuki fase stasioner yang dilanjutkan fase kematian. Hal ini juga diikuti dengan penurunan aktivitas enzim, penurunan aktivitas spesifik $\alpha$-amilase yang terjadi diduga karena Aspergillus sp. juga mengeluarkan protease dan glikosidase. Pada beberapa kasus, pada saat sel mengalami lisis, enzim seperti protease dihasilkan (Madigan et al., 2003) dan dapat menguraikan protein enzim $\alpha$-amilase yang menyebabkan turunnya aktivitas enzim.

Bobot kering miselium A. versicolor $3 \mathrm{a} 1$ pada ketiga perlakuan media mengalami penurunan setelah akhir fase eksponensial, begitu juga dengan produksi $\alpha$-amilasenya. Nahas dan Waldemarin (2002) melaporkan amilase yang diproduksi oleh Aspergillus ochraceus mempunyai pertumbuhan maksimum setelah 5 hari inkubasi pada suhu $30^{\circ} \mathrm{C}$, tetapi produksi amilase maksimumnya setelah 2 hari inkubasi. Produksi amilasenya tertinggi dengan menggunakan laktosa, maltosa, silosa, dan pati sebagai sumber karbon, dengan $\mathrm{pH}$ optimum pada $\mathrm{pH} 5,0$.

\section{Produksi Ekstrak Kasar $\alpha$-Amilase, Pengendapan dengan Amonium Sulfat, dan Dialisis}

Ekstrak kasar enzim $\alpha$-amilase $A$. versicolor 3a1 yang diproduksi pada media limbah memiliki aktivitas spesifik sebesar 7,57 $\mathrm{U} / \mathrm{mg}$, setelah diendapkan dengan amonium sulfat aktivitas spesifik tertinggi sebesar 9,29 $\mathrm{U} / \mathrm{mg}$ dicapai pada pengendapan amonium sulfat $70 \%$ (w/v) (Gambar 2a). Pada media dasar, ekstrak kasar enzim $\alpha$-amilase memiliki aktivitas spesifik sebesar 7,30 U/mg, setelah diendapkan dengan amonium sulfat menunjukkan aktivitas spesifik tertinggi sebesar $20,14 \mathrm{U} / \mathrm{mg}$ yang dicapai pada pengendapan amonium sulfat $60 \%$ (w/v) (Gambar 2b). Aktivitas spesifik ekstrak kasar enzim $\alpha$ amilase pada media kombinasi sebesar 14,78 $\mathrm{U} / \mathrm{mg}$, setelah diendapkan dengan amonium sulfat aktivitas spesifik tertinggi dicapai pada pengendapan amonium sulfat $60 \%$ (w/v) yaitu sebesar 16,07 U/mg (Gambar 2c).

Setelah dilakukan produksi enzim kembali dari media limbah didapatkan tingkat kemurnian dan perolehan enzim $\alpha$-amilase $A$. versicolor 3a1 tertinggi yaitu tingkat 
kemurniannya 16,60 kali dibanding ekstrak kasarnya dan perolehannya 59,84\% (Tabel 1). Setelah kadar penggaraman optimum tercapai, aktivitas enzim mengalami penurunan, hal ini antara lain karena sebagian protein mengalami denaturasi dan rusak oleh pengaruh perlakuan selama pengendapan (Fogarty, 1983).

Enzim kemudian didialisis untuk mengeluarkan senyawa-senyawa pengotor yang terdapat pada larutan enzim. Hasil dialisis menunjukkan terdapat kenaikan aktivitas enzim $\alpha$-amilase sebesar $88,3 \%$ dibandingkan sebelum dialisis. Ramachandran et al., (2004) melaporkan, aktivitas spesifik optimum $\alpha$ amilase A.oryzae $(78,1 \mathrm{U} / \mathrm{mg})$ dicapai pada kadar amonium sulfat 40-70\%. Michelena dan Castillo (1984) juga melaporkan bahwa enzim amilase $A$. foetidus yang diproduksi pada media tepung beras aktivitasnya mengalami peningkatan 11 kali setelah pengendapan dengan amonium sulfat. Amonium sulfat disukai karena kelarutannya tinggi, harganya murah, dan umumnya tidak mempengaruhi struktur protein.

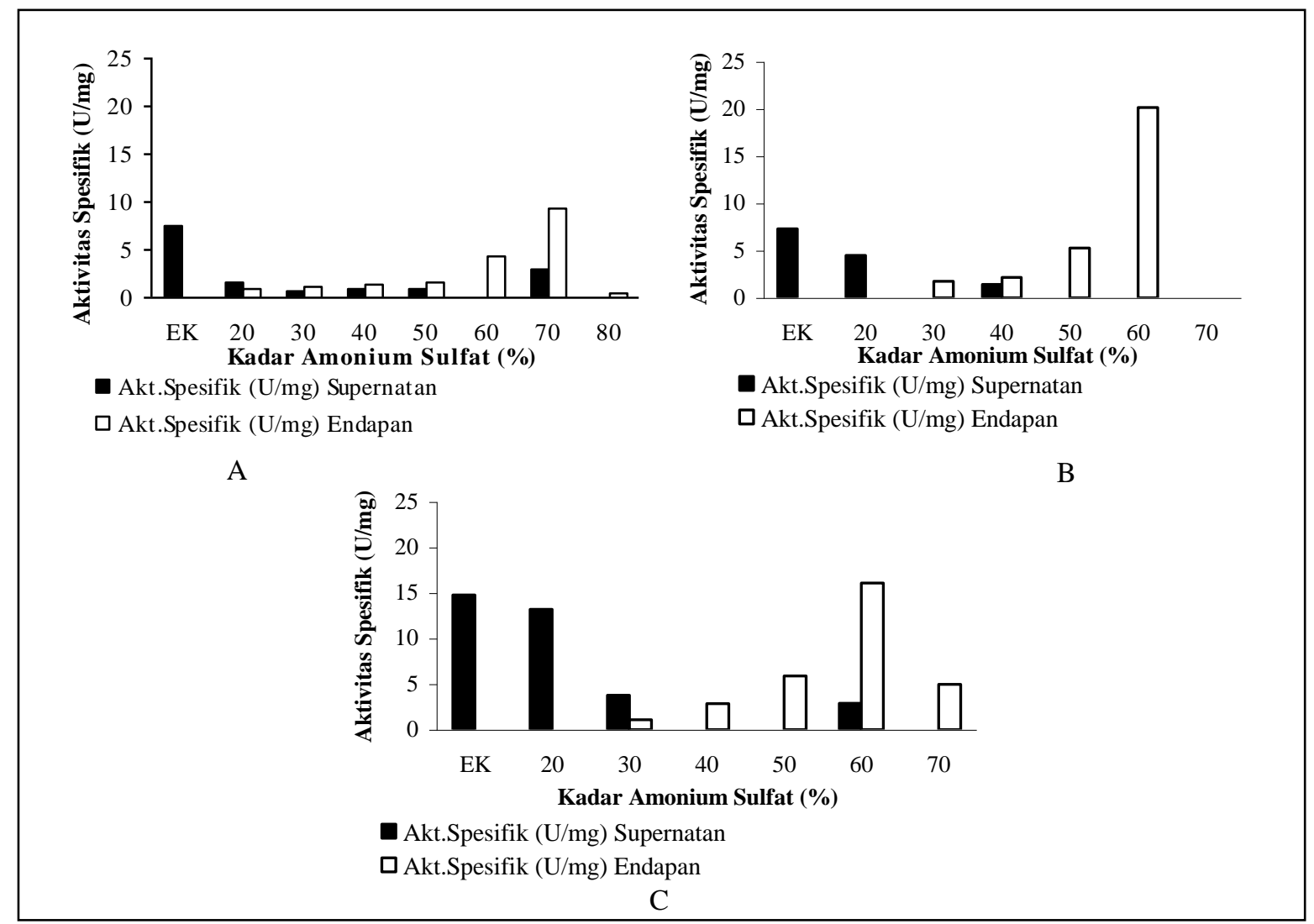

Gambar 2. Aktivitas spesifik enzim $\alpha$-amilase A. versicolor $3 \mathrm{a} 1$ yang diproduksi pada media a: limbah, b: dasar, c: kombinasi, yang diendapkan dengan kadar amonium sulfat yang berbeda. EK merupakan enzim ekstrak kasar yang belum mendapat perlakuan pengendapan amonium sulfat.

Tabel 1. Tingkat kemurnian dan perolehan aktivitas enzim $\alpha$-amilase A. versicolor 3a1 pada berbagai media.

\begin{tabular}{cccccccc}
\hline \hline Media & Perlakuan & $\begin{array}{c}\text { Volume } \\
(\mathbf{m l})\end{array}$ & $\begin{array}{c}\text { Aktivitas } \\
(\mathbf{U})\end{array}$ & $\begin{array}{c}\text { Kadar Protein } \\
(\mathbf{m g})\end{array}$ & $\begin{array}{c}\text { Aktivitas Spesifik } \\
(\mathbf{U} / \mathbf{m g})\end{array}$ & $\begin{array}{c}\text { Tingkat } \\
\text { Kemurnian }\end{array}$ & $\begin{array}{c}\text { Perolehan } \\
(\boldsymbol{\%})\end{array}$ \\
\hline \hline Limbah & EK & 800,00 & 607,62 & 416 & 1,46 & 1,00 & 100,00 \\
& HP 70\% & 50,00 & 363,57 & 15,00 & 24,24 & 16,60 & 59,84 \\
\hline Dasar & EK & 700,00 & 1806,73 & 462 & 3,91 & 1,00 & 100,00 \\
& HP 60\% & 50,00 & 527,77 & 31,50 & 16,75 & 4,28 & 29,21 \\
\hline Kombi- & EK & 700,00 & 2064,49 & 427 & 4,83 & 1,00 & 100,00 \\
nasi & HP 60\% & 50,00 & 777,08 & 28,50 & 27,27 & 5,65 & 37,64 \\
\hline \hline
\end{tabular}

Keterangan : pengukuran aktivitas pada suhu $30^{\circ} \mathrm{C}$ dan $\mathrm{pH} 7,0$

$\mathrm{EK}=$ ekstrak kasar; $\mathrm{HP}=$ hasil pengendapan amonium sulfat 
Media limbah sebelum diinokulasikan biakan mengandung protein yang tinggi dibanding dua media lainnya, tetapi setelah diproduksi dalam $500 \mathrm{ml}$ media, pada media limbah didapatkan protein dalam jumlah yang lebih kecil dibanding dua media lainnya (Tabel 2). Aktivitas enzim $\alpha$-amilase dan kadar protein A. versicolor $3 \mathrm{a} 1$ yang diproduksi pada media limbah paling kecil bila dibandingkan dengan kedua perlakuan media lainnya, sehingga aktivitas spesifik yang didapatkan paling tinggi.

Kadar protein $A$. versicolor $3 \mathrm{a} 1$ yang bersisa $38 \%$ dan hilang sebanyak $62 \%$ setelah didialisis, hal ini dapat disebabkan terjadinya denaturasi protein pada saat perlakuan dialisis yang menyebabkan sebagian protein terurai dan rusak. Menurut Scopes (1987) selama dialisis berlangsung kemungkinan terjadi degradasi oleh enzim protease yang terdapat pada enzim yang masih belum dimurnikan, sehingga dapat menurunkan kadar protein dan aktivitas enzim. Nilai aktivitas enzim $\alpha$-amilase $A$. versicolor $3 \mathrm{a} 1$ setelah didialisis juga mengalami penurunan dibandingkan sebelum didialisis, hal ini diduga karena adanya sebagian protein yang mengalami denaturasi. Adapun aktivitas spesifik yang lebih tinggi setelah dialisis disebabkan kadar protein setelah dialisis mengalami penurunan sehingga dapat meningkatkan aktivitas spesifiknya.

\section{Karakterisasi $\alpha$-Amilase}

Aktivitas spesifik tertinggi ekstrak kasar $\alpha$-amilase A. versicolor 3 a 1 pada media limbah, dasar, dan kombinasi dicapai pada suhu $70^{\circ} \mathrm{C}$, masing-masing sebesar $13,16 \mathrm{U} / \mathrm{mg}, \quad 37,70$ $\mathrm{U} / \mathrm{mg}$, dan 38,52 U/mg. Aktivitas mengalami penurunan pada suhu $80^{\circ} \mathrm{C}$ (Gambar 3a). Demikian juga dengan aktivitas spesifik hasil pengendapan, didapatkan optimum pada suhu $70^{\circ} \mathrm{C}$, masing-masing sebesar $133,06 \mathrm{U} / \mathrm{mg}$, $118,51 \mathrm{U} / \mathrm{mg}$ dan $155,42 \mathrm{U} / \mathrm{mg}$, aktivitas juga mengalami penurunan pada suhu $80^{\circ} \mathrm{C}$ (Gambar 3b).

Tabel 2. Hasil dialisis enzim $\alpha$-amilase A. versicolor $3 \mathrm{a} 1$ hasil pengendapan amonium sulfat pada media dasar.

\begin{tabular}{cccccc}
\hline \hline \multicolumn{3}{c}{ Sebelum dialisis } & \multicolumn{3}{c}{ Setelah dialisis } \\
\hline $\begin{array}{c}\text { Kadar Protein } \\
(\mathbf{m g})\end{array}$ & $\begin{array}{c}\text { Aktivitas Unit } \\
(\mathbf{U})\end{array}$ & $\begin{array}{c}\text { Aktivitas spesifik } \\
(\mathbf{U} / \mathbf{m g})\end{array}$ & $\begin{array}{c}\text { Kadar Protein } \\
(\mathbf{m g})\end{array}$ & $\begin{array}{c}\text { Aktivitas Unit } \\
(\mathbf{U})\end{array}$ & $\begin{array}{c}\text { Aktivitas spesifik } \\
(\mathbf{U} / \mathbf{m g})\end{array}$ \\
\hline \hline 31,50 & 895,04 & 28,40 & 12,00 & 641,78 & 53,48 \\
\hline \hline
\end{tabular}

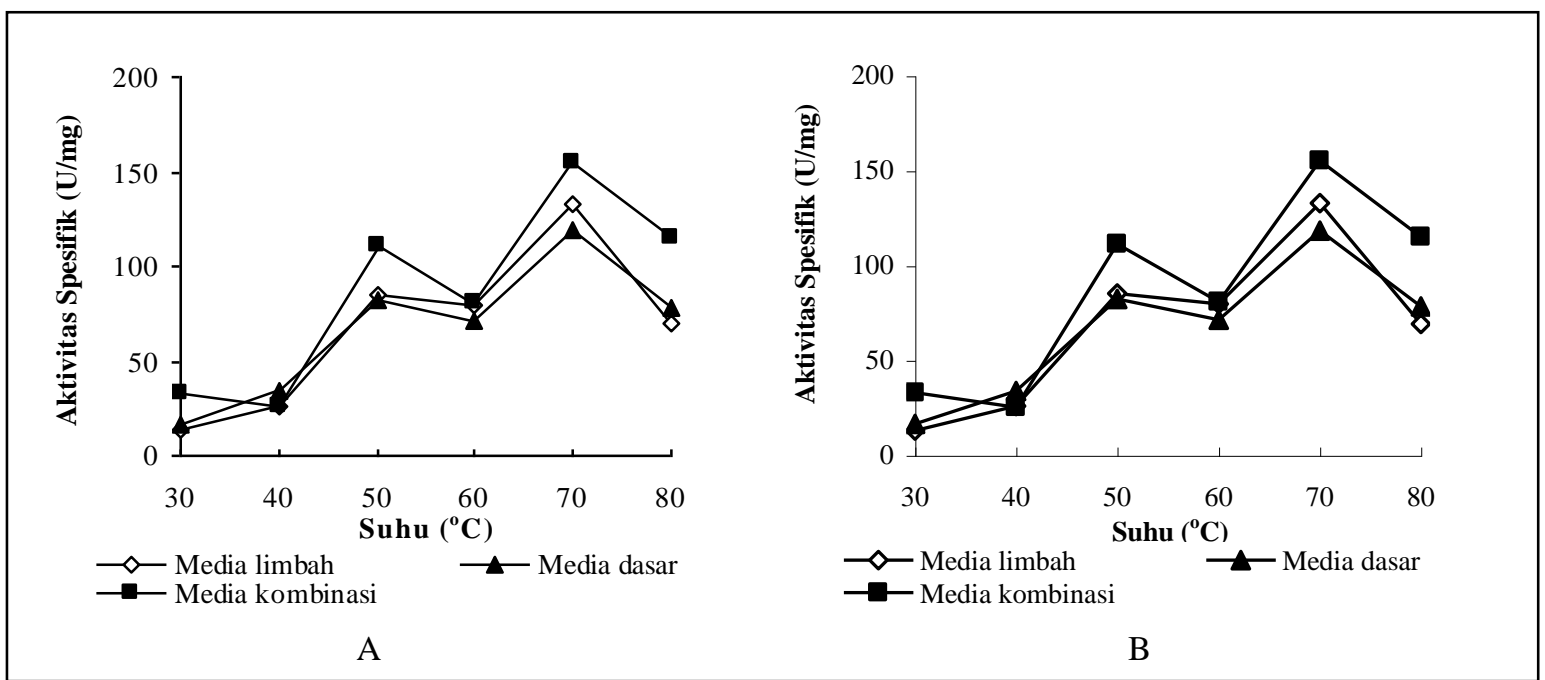

Gambar 3. Aktivitas spesifik $\alpha$-amilase A. versicolor 3a1 a: ekstrak kasar dan b: hasil pengendapan yang diproduksi pada media limbah, dasar, dan kombinasi pada berbagai suhu. Aktivitas diukur pada $\mathrm{pH} 7,0$. 
Aktivitas spesifik ekstrak kasar $\alpha-$ amilase A. versicolor $3 \mathrm{a} 1$ baik pada media limbah, dasar, dan kombinasi optimum pada pH 5,0, masing-masing sebesar 26,13 U/mg, $30,89 \mathrm{U} / \mathrm{mg}$ dan 34,33 U/mg (Gambar 4a). Aktivitas spesifik $\alpha$-amilase hasil pengendapan optimum pada $\mathrm{pH}$ 6,0, masing-masing untuk ketiga media di atas sebesar 131,24 U/mg, 360,64 U/mg, dan 195,25 U/mg (Gambar 4b).

Suhu dan $\mathrm{pH}$ berpengaruh terhadap aktivitas enzim. Enzim $\alpha$-amilase akan menghasilkan aktivitas maksimal apabila dikondisikan pada $\mathrm{pH}$ dan suhu optimumnya. Ekstrak kasar enzim $\alpha$-amilase A.versicolor 3a1 pada media limbah, dasar, dan kombinasi mempunyai suhu optimum yang sama dengan enzim hasil pengendapan pada ketiga perlakuan media, yaitu $70^{\circ} \mathrm{C}$. Inkubasi $\alpha$-amilase A.versicolor $3 \mathrm{a} 1$ pada suhu $80^{\circ} \mathrm{C}$ memiliki nilai aktivitas lebih rendah dari pada suhu optimumnya. Penurunan aktivitas ini dapat disebabkan oleh denaturasi protein.

Pada umumnya, pengaruh suhu terhadap produksi amilase bergantung dari pertumbuhan organisme penghasilnya. Contohnya, cendawan mesofilik, seperti A. ficuum, memproduksi amilase pada suhu $30^{\circ} \mathrm{C}$. Sedangkan cendawan termofilik, seperti Thermomonospora fusca, optimum menghasilkan amilase pada suhu 50$55^{\circ} \mathrm{C}$ (Sivaramakrishnan et al., 2006). Secara ekonomis untuk penggunaan amilase lebih disukai yang aktif pada suhu tinggi untuk proses gelatinisasi $\left(100-110^{\circ} \mathrm{C}\right)$ dan liquifikasi $\left(80-90^{\circ} \mathrm{C}\right)$.

Semua reaksi enzim dipengaruhi oleh $\mathrm{pH}$ medium tempat reaksi terjadi. Pada umumnya enzim aktif pada $\mathrm{pH}$ netral, yakni $\mathrm{pH}$ cairan makhluk hidup. Aktivitas spesifik ekstrak kasar enzim $\alpha$-amilase A.versicolor $3 \mathrm{a} 1$ pada media limbah, dasar, dan kombinasi optimum pada $\mathrm{pH}$ 5.0, sedangkan aktivitas spesifik enzim hasil pengendapan pada ketiga perlakuan media optimum pada $\mathrm{pH}$ 6,0. Perbedaan $\mathrm{pH}$ optimum antara ekstrak kasar dan enzim hasil pengendapan ini disebabkan perbedaan faktor lingkungan antara ekstrak kasar yang masih terdiri atas substrat, sedangkan enzim hasil pengendapan sudah terpisah dari substrat dan dilarutkan di dalam bufer Tris- $\mathrm{HCl} 0,05 \mathrm{M} \mathrm{pH}$ 7,0. Aktivitas $\alpha$-amilase secara umum berada pada kisaran $\mathrm{pH} 4,8$ - 6,5, namun $\mathrm{pH}$ optimum ini dapat berbeda tergantung dari sumber penghasil enzimnya (Fogarty, 1983; Sivaramakrishnan et al., 2006).

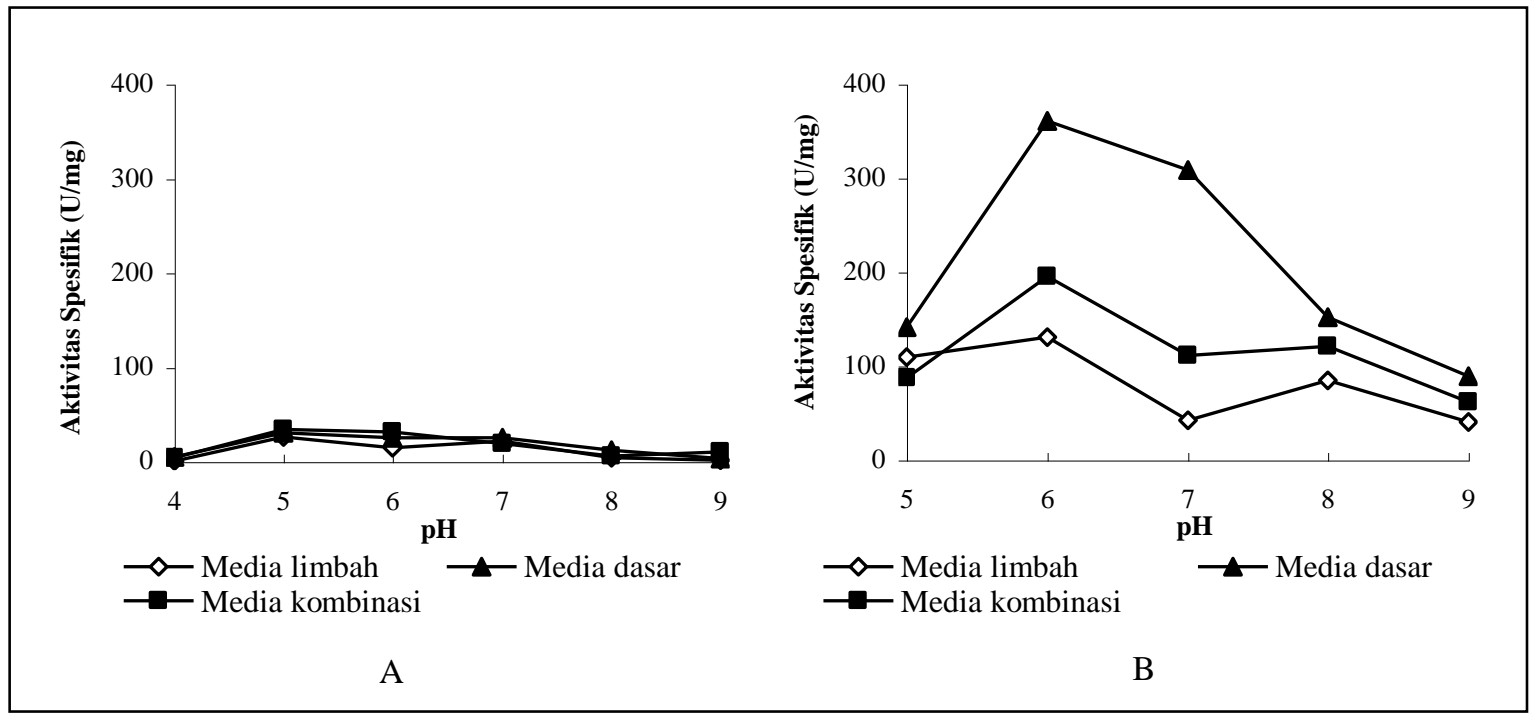

Gambar 4. Aktivitas spesifik $\alpha$-amilase A. versicolor $3 \mathrm{a} 1$ a: ekstrak kasar dan b: hasil pengendapan yang diproduksi pada media limbah, dasar, dan kombinasi pada berbagai pH. Aktivitas diukur pada suhu optimum. 
Selain jenis dan kadar substrat, suhu, serta $\mathrm{pH}$, kecepatan hidrolisis pati oleh enzim $\alpha$-amilase dipengaruhi oleh kofaktor, seperti ion logam. Sebagian besar amilase tergolong enzim yang tergantung pada ion logam untuk aktivitasnya (Sivaramakrishnan et al., 2006). Dari hasil karakterisasi kation pada ekstrak kasar untuk ketiga perlakuan media, didapatkan aktivitas spesifik optimum dengan penambahan $\mathrm{FeSO}_{4}$. Aktivitas spesifik ekstrak kasar $\alpha$ amilase A. versicolor $3 \mathrm{a} 1$ pada media limbah, dasar, dan kombinasi tertinggi dengan penambahan $\mathrm{FeSO}_{4}$, masing-masing sebesar 288,63 U/mg, 158,39 U/mg, dan 905,39 U/mg (Gambar 5a). Aktivitas spesifik $\alpha$-amilase hasil pengendapan tertinggi dengan penambahan $\mathrm{FeSO}_{4}$ pada media dasar dan kombinasi masing-masing sebesar 464,19 U/mg dan $316,97 \mathrm{U} / \mathrm{mg}$ (Gambar 5b). Contoh $\alpha$-amilase yang diaktifkan oleh $\mathrm{Fe}^{2+}$ yang berasal dari Bacillus sp. I-3 (Sivaramakrishnan et al., 2006). $\mathrm{Fe}^{2+}$ merupakan kofaktor yang banyak terlibat dalam pengaturan kehidupan organisme (Whitaker, 1994).

Aktivitas spesifik ekstrak kasar enzim $\alpha$ amilase dan enzim hasil pengendapan pada ketiga perlakuan media juga mengalami kenaikan pada penambahan ion $\mathrm{CaCl}_{2}$. Keberadaan ion kalsium akan menstabilkan aktivitas enzim, terutama termostabilitasnya. Hal ini disebabkan oleh salting out residu hidrofobik oleh $\mathrm{Ca}^{2+}$ di dalam protein yang menyebabkan struktur protein menjadi kompak (Sivaramakrishnan et al., 2006).

Aktivitas spesifik ekstrak kasar enzim $\alpha$ amilase dan enzim hasil pengendapan pada ketiga perlakuan media mengalami penurunan ketika ditambah senyawa pengkelat logam (EDTA) (Lin et al., 1998). EDTA merupakan penghambat metaloenzim dan penghambat kuat terhadap amilase dari Myxococcus coralloides dan Schwanniomyces alluvius (Lin et al., 1998). Penurunan aktivitas $\alpha$-amilase setelah direaksikan dengan EDTA menunjukkan bahwa enzim tersebut membutuhkan ion logam untuk aktivitasnya.

\section{Kestabilan Suhu dan pH $\alpha$-Amilase}

Aktivitas spesifik ekstrak kasar $\alpha$-amilase A. versicolor 3 a1 pada media limbah, dasar, dan kombinasi yang diinkubasi pada suhu optimum $70^{\circ} \mathrm{C}$ dengan penambahan $\mathrm{FeSO}_{4}$ relatif stabil (Gambar 6a). Aktivitas spesifik $\alpha$ amilase hasil pengendapan dengan penambahan $\mathrm{FeSO}_{4}$ pada media limbah cenderung menurun, namun pada media dasar dan kombinasi relatif stabil pada menit ke-90 hingga 180 (Gambar $6 b)$.

Aktivitas spesifik ekstrak kasar $\alpha$ amilase A. versicolor 3 al relatif stabil pada kisaran pH 5 hingga 9 dan aktivitasnya tetap tinggi pada $\mathrm{pH}$ optimumnya 5,0 (Gambar 7a). Aktivitas spesifik $\alpha$-amilase $A$. versicolor $3 \mathrm{a} 1$ hasil pengendapan menunjukkan kisaran $\mathrm{pH}$ yang sempit dan aktivitas tetap tinggi pada $\mathrm{pH}$ optimumnya 6,0 (Gambar 7b).

Stabilitas $\mathrm{pH}$ suatu enzim dipengaruhi oleh banyak faktor, antara lain, suhu, waktu inkubasi, denaturasi protein, jenis dan kadar bufer yang digunakan, kehadiran atau ketidakhadiran substrat, dan proteolisis. Stabilitas $\mathrm{pH}$ enzim juga dipengaruhi oleh kehadiran atau ketidakhadiran kofaktor atau molekul kecil lainnya (Whitaker, 1994).

Enzim dengan kestabilan pada kisaran $\mathrm{pH}$ yang luas ini, terutama enzim yang masih memiliki aktivitas pada $\mathrm{pH}$ yang tinggi (basa) dapat diaplikasikan pada industri seperti detergen. Dari hasil penelitian ini dapat dilihat bahwa aktivitas enzim cukup tinggi, dan dapat digunakan pada substrat yang mengandung pati terutama limbah tapioka, untuk menghasilkan produk-produk yang diinginkan seperti maltosa, maltotriosa, glukosa, dan dekstrin sehingga selain mendapatkan produk-produk yang diinginkan tersebut, dapat pula memanfaatkan limbah cair tapioka yang biasanya dibuang dan sering kali menimbulkan masalah lingkungan (Mubarik et al., 2004). Selain itu juga, ekstrak kasar enzim $\alpha$-amilase $A$. versicolor $3 \mathrm{a} 1$ yang belum dimurnikan ini mungkin dapat dimanfaatkan pada industri-industri selain makanan, karena menurut Shambe dan Ejembi (1986) ekstrak kasar enzim efektif dalam memproduksi monosakarida yang dapat digunakan dalam fermentasi atau memproduksi glukosa dari pati atau bahan yang mengandung pati. 


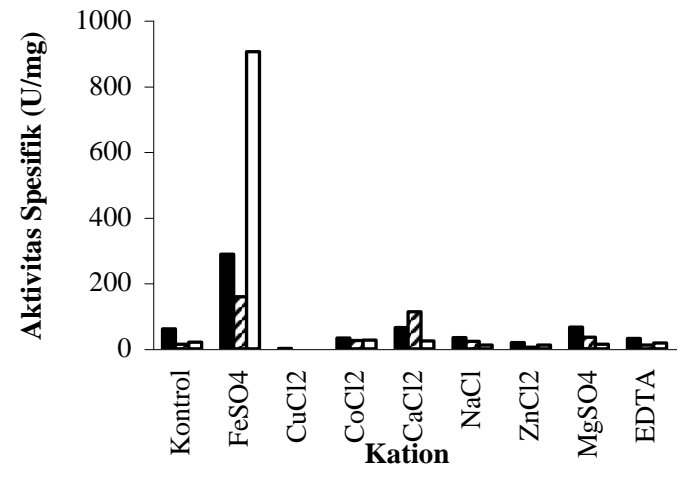

Media limbah $\square$ Media dasar $\square$ Media kombinasi A

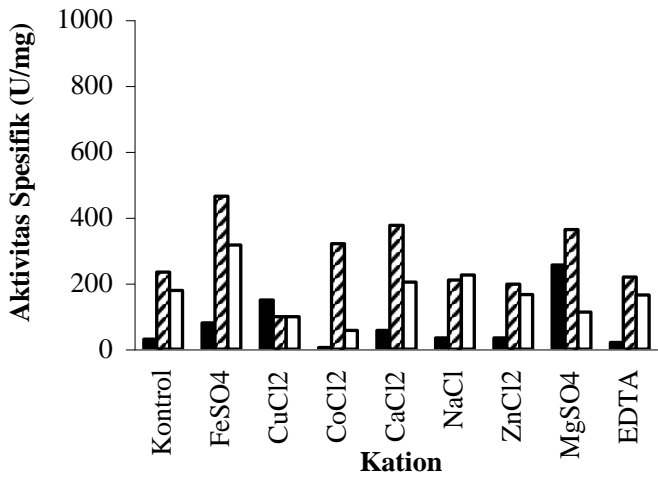

— Media limbah $\boldsymbol{\square}$ Media dasar $\mathbf{\square}$ Media kombinasi B

Gambar 5. Pengaruh kation dan EDTA terhadap aktivitas spesifik $\alpha$-amilase A. versicolor 3a1 a: ekstrak kasar dan b: hasil pengendapan yang diproduksi pada media limbah, dasar, dan kombinasi.

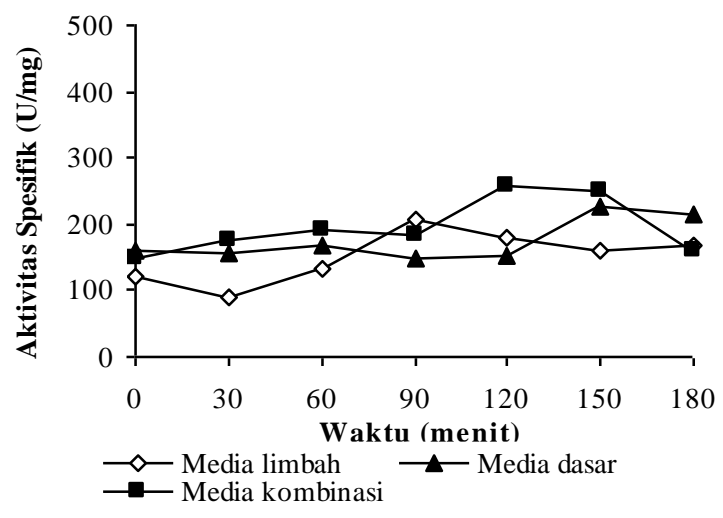

A

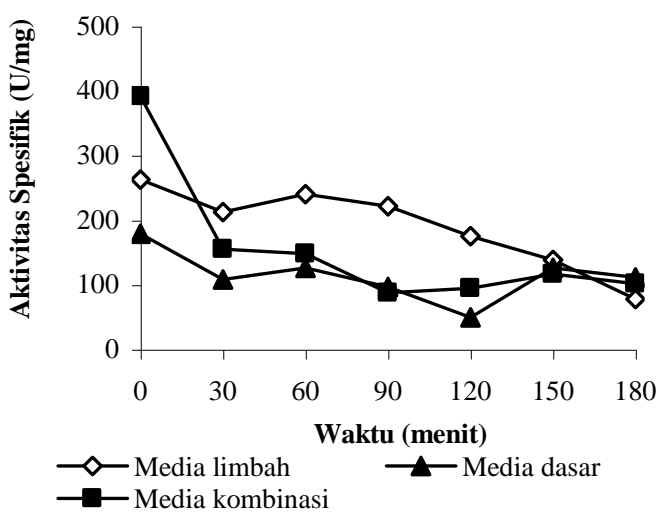

B

Gambar 6. Kestabilan $\alpha$-amilase $A$. versicolor $3 \mathrm{a} 1$ a: ekstrak kasar dan b: hasil pengendapan dengan penambahan $\mathrm{FeSO}_{4}$ pada suhu $70^{\circ} \mathrm{C}$ selama 180 menit inkubasi pada $\mathrm{pH}$ optimum masing-masing.

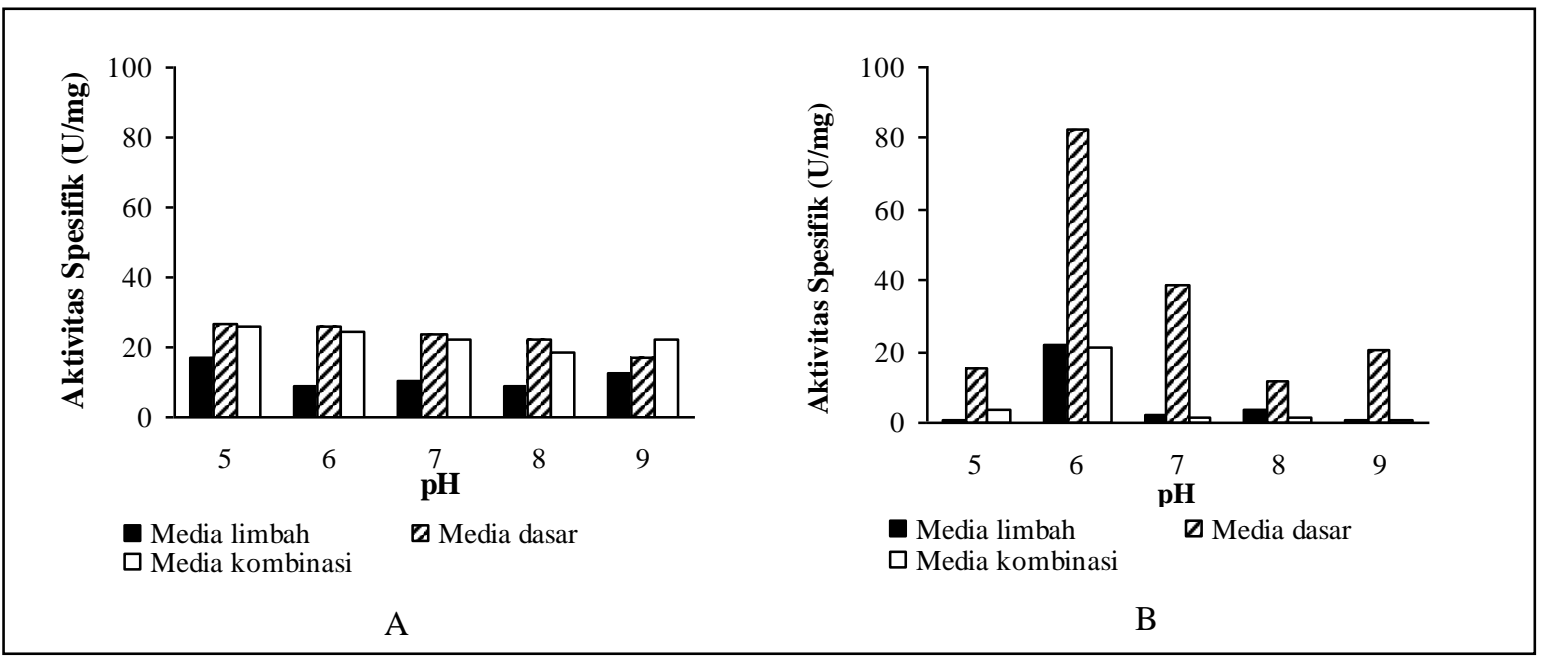

Gambar 7. Kestabilan $\mathrm{pH}$ aktivitas spesifik $\alpha$-amilase A. versicolor 3a1 a: ekstrak kasar dan b: hasil pengendapan pada suhu $30^{\circ} \mathrm{C}$ selama 1 jam inkubasi. 


\section{Kesimpulan dan Saran}

\section{Kesimpulan}

Aspergillus versicolor 3a1 terbukti berpotensi menghasilkan $\alpha$-amilase. Bobot kering sel dan aktivitas spesifik $\alpha$-amilase $A$. versicolor 3a1 yang ditumbuhkan pada media limbah optimum pada hari ke-3, sedangkan pada media dasar dan kombinasi masingmasing pada hari ke-7 dan ke-4. Pengendapan amonium sulfat enzim pada media limbah optimum pada kadar $70 \%$, sedangkan media dasar dan kombinasi pada kadar 60\%. Enzim $\alpha$-amilase 3a1 ekstrak kasar dan hasil pengendapan pada media limbah optimum pada suhu $70^{\circ} \mathrm{C}, \mathrm{pH}$ optimum 5,0 untuk ekstrak kasar dan 6,0 untuk enzim hasil pengendapan, demikian pula dengan dua media lainnya. Penambahan $\mathrm{FeSO}_{4}$ meningkatkan aktivitas spesifik ekstrak kasar 3a1 pada ketiga media. Ekstrak kasar enzim 3a1 pada ketiga perlakuan media relatif stabil pada suhu $70^{\circ} \mathrm{C}$ selama 180 menit inkubasi, sedangkan enzim hasil pengendapan media limbah cenderung menurun, dua media lainnya relatif stabil. Ekstrak kasar 3a1 pada media limbah dan dua media lainnya relatif stabil dengan kisaran $\mathrm{pH}$ yang luas, sedangkan enzim hasil pengendapan media limbah dan dua media lainnya mempunyai kisaran $\mathrm{pH}$ yang sempit.

\section{Saran}

Enzim yang berasal dari isolat Aspergillus versicolor 3a1 perlu dilakukan dialisis dan pemurnian enzim lebih lanjut agar didapatkan enzim yang lebih murni dan mempunyai aktivitas yang lebih tinggi. Penelitian lebih lanjut juga perlu dilakukan untuk mengetahui jenis produk akhir seperti maltosa, maltotriosa, dan maltooligosakarida lainnya dari hasil hidrolisis enzim $\alpha$-amilase kedua isolat dengan menggunakan substrat limbah cair tapioka dan media kombinasi.

\section{Ucapan Terima Kasih}

Penelitian ini menggunakan bahan-bahan kimia yang diperoleh dari NRM.

\section{Daftar Pustaka}

Bradford, M.M. 1976. A rapid and sensitive method for the quantitation on microgram quantities of protein in utilizing the principle of protein dye binding. Anal. Biochem. 72: 248-254.

Djubaedah, E., Noerdin, M. dan Harijanto, S. 1994. Penanggulangan limbah cair tapioka secara kimia. J. Agric. Indust. 11: 28-33.

Fogarty, W.M. 1983. Microbial amylases. In: Fogarty, W.M. (Eds). Microbial Enzymes and Biotechnology, pp. 1-92. Applied Science Publishers, London.

Griffin, D.H. 1994. Fungal Physiology. Ed ke-2. WileyLiss, Inc., New York.

Handayani, D., Mubarik, N.R. dan Listiyowati, S. 2002. Komunikasi Singkat. Isolasi dan karakterisasi $\alpha$-amilase ekstraseluler dari kapang asal limbah cair tapioka. J. Mikrobiol. Indones. 7: 51-54.

Lin, C.L., Chyau, C.C. and Hsu, W.H. 1998. Production and properties of a raw starch-degrading amylase from the thermophilic and alkaliphilic Bacillus sp. TS-23. Biotechnol. Appl. Biochem. 28: 61-68.

Madigan, M.T., Martinko, J.M. and Parker, J. 2003. Brock Biology of Microorganisms. 9th Ed. PrenticeHall, Inc., New Jersey.

Michelena, V.V. and Castillo, F.J. 1984. Production of amylase by Aspergillus foetidus on rice flour medium and characterization of the enzyme. $J$. Appl. Bacteriol. 3: 395-407.

Mubarik, N.R., Damayanti, E. dan Listiyowati, S. 2003. Isolasi dan karakterisasi amilase dari kapang alkalotoleran asal limbah cair tapioka. Biota VIII (1): 1-8.

Mubarik, N.R., Iswati, R. dan Imas, T. 2004. Karakterisasi $\alpha$-amilase Bacillus firmus KH.9.4 Alkalotoleran dari Limbah Cair Tapioka. Biota IX (3): 129-135.

Mubarik, N.R. 2005. Komunikasi Singkat. Analisis zimogram $\alpha$-amilase mikrob toleran basa. $J$. Mikrobiol. Indones. 10: 48-50.

Nahas, E. and Waldemarin, M.M. 2002. Control of amylase production and growth characteristics of Aspergillus ochraceus. Rev. Latin. Microbiol. 44: 5-10.

Naiola, E. 2002. Karakterisasi dan optimasi media produksi amilase dari Aspergillus niger dan Aspergillus clavatus. Bogor: Berita Biologi, Bidang Mikrobiologi, Puslit Biologi - LIPI, Bogor. 
Ramachandran, S., Patel, A.K., Nampoothiri, K.M., Chandran, S., Szakacs, G., Soccol, C.R. and Pandey, A. 2004. Alpha amylase from a fungal culture grown on oil cakes and its properties. Braz. Arch. Biol. Technol. 47 (2): 309-317.

Shambe, T. and Ejembi, O. 1986. Production of Amylase and Cellulase: Degradation of Starch and Carboxymethylcellulose by Extracellular Enzymes from Four Fungal Species. Department of Chemistry, University of Jos, Nigeria.
Sivaramakrishnan, S., Gangadharan, D., Nampoothiri, K.M., Soccol, C.R. and Pandey, A. 2006. $\alpha-$ Amylases from microbial sources - an overview on recent developments. Food Technol. Biotechnol. 44 (2): 173-184.

Scopes, R.K. 1987. Protein Purification: Principles and Practice. 2nd Ed. Springer Verlag, New York.

Whitaker, J.R. 1994. Principles of Enzymology for the Food Sciences. 2nd Ed. Department of Food Science and Technology Davis College of Agricultural and Environmental Sciences University of California, California. 